\title{
Effects of pholcodine and salbutamol on citric acid induced cough in normal subjects
}

\author{
N BELCHER, PJ REES \\ From the Respiratory Function Laboratory, Guy's Hospital, London
}

Cough may be the presenting feature of asthma in adults and children. ${ }^{12}$ Treatments for asthma, such as $\beta$ stimulant drugs, are known to be effective in controlling the symptom. ${ }^{1}$ Ellul-Micaleff demonstrated the efficacy of oral terbutaline sulphate in a double blind, placebo controlled crossover study of 30 patients with chronic "allergic" cough. ${ }^{3}$ In whooping cough inhaled salbutamol has been found to reduce the frequency and intensity of the whoop but not the cough. ${ }^{4}$ In contrast, Pavesio and Ponzone found a reduction in cough as well as whoop with oral salbutamol. 5

The effectiveness of antitussive agents has been assessed most often by their action on cough induced by agents such as citric acid rather than spontaneous cough. Many techniques have been used to assess these effects. ${ }^{6}$ We have used the technique of establishing the threshold for citric acid induced coughs ${ }^{7}$ to compare the actions of placebo, oral salbutamol, oral pholcodine, and their combination in nine non-asthmatic subjects. Pholcodine has been shown to raise the threshold of coughing in response to citric acid inhalation ${ }^{8}$ and was included in this study as a positive control.

\section{Methods}

Ten normal, non-asthmatic subjects from the staff of the hospital, and medical school volunteered for the study. None was taking any medication. All subjects were nonsmokers. Approval was obtained from the local ethical committee.

The design was a placebo controlled, double blind, crossover study using a double dummy technique. On four days one week apart, at the same time of day, subjects received the following four combinations of syrup in randomised order according to a four way Williams square: (a) $10 \mathrm{ml}$ placebo pholcodine and $10 \mathrm{ml}(4 \mathrm{mg})$ salbutamol; (b) $10 \mathrm{ml}$ $(10 \mathrm{mg})$ pholcodine and $10 \mathrm{ml}$ placebo salbutamol; (c) $10 \mathrm{ml}$ (10 mg) pholcodine and $10 \mathrm{ml}(4 \mathrm{mg})$ salbutamol; (d) $10 \mathrm{ml}$ placebo pholcodine and $10 \mathrm{ml}$ placebo salbutamol.

The citric acid challenge was given as three inhalations of doubling concentrations of citric acid, beginning at $1.25 \%$ and ceasing when all three inhalations at one concentration produced an immediate cough, or at $80 \%$ citric acid.

Citric acid was inhaled from a Hudson nebuliser driven from an air cylinder at $20 \mathrm{lb} / \mathrm{in}^{2}(137.8 \mathrm{kPa})$. A dosimeter delivered aerosol for one second of a tidal breath and was

Address for reprint requests: Dr John Rees, Guy's Hospital, London SE1 9RT.

Accepted 1 Julv 1985 triggered by negative mouth pressure at the beginning of inspiration. Subjects practised the technique before the study and throughout they were encouraged to take inspirations of similar depth and inspiratory flow rate. Subjects $\nexists$ waited for two minutes between inhalations of incremental $\rightarrow$ citric acid concentrations while the nebuliser solution was $\stackrel{\sim}{\perp}$ changed.

On each study day the citric acid cough threshold was measured, $10 \mathrm{ml}$ of both test syrups were given, and the $\vec{c}$ threshold was measured again two hours later.

The output of the nebulising system was assessed at different concentrations of citric acid. Output was constant below $80 \%$ citric acid but at this concentration the volume of each nebulisation fell by $58 \%$. Coughing usually occurred $\bigoplus$ during a nebulisation, suggesting that concentration and not the total amount of citric acid is important in inducing cough.

Citric acid thresholds before and after each treatment were compared by the Wilcoxon matched pairs signed rank test.

\section{Results}

Citric acid cough thresholds before and after the four treatments are shown in the table. There was considerable variation in the pretreatment cough thresholds between individuals. For any individual, however, the pretreatment cough threshold was fairly consistent. One subject was excluded because of the development of an upper respiratory tract ? infection. This individual showed a variable baseline. Only one other subject varied by more than one concentration difference over the four days. There was no relationship between threshold and week of the trial (Friedman two way analysis of variance: $\chi^{2}{ }_{r}=2.51,0.3<p<0.5$ ), suggesting that there was no learning effect or adaptation over the trial.

There were no significant differences between pretreatment and post treatment cough thresholds on placebo $\mathrm{N}$ or salbutamol days. Administration of pholcodine, however, was associated with a significant increase in cough threshold $N$ when given alone (Wilcoxon matched pairs signed ranks $\omega$ test, $\mathrm{p}<0.05$ ) or in combination with salbutamol $(\mathrm{p}<0$ 0.05 ). The degree of change in threshold produced by pholcodine was not increased by combination with salbutamol.

\section{Discussion}

Although oral $\beta$ stimulants have been found to be effective in "allergic" cough, ${ }^{3}$ there is no general agreement about the $\varrho$

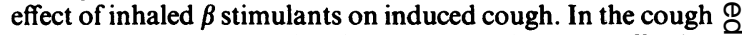
of whooping cough oral salbutamol may be more effective 
Threshold concentrations ( $\%$ ) of citric acid

\begin{tabular}{|c|c|c|c|c|c|c|c|c|}
\hline \multirow{2}{*}{$\begin{array}{l}\text { Subject } \\
\text { No }\end{array}$} & \multicolumn{2}{|l|}{ Placebo } & \multicolumn{2}{|c|}{ Salbutamol } & \multicolumn{2}{|c|}{ Pholcodine } & \multicolumn{2}{|c|}{ Combination } \\
\hline & Before & After & Before & After & Before & After & Before & After \\
\hline $\begin{array}{l}1 \\
2 \\
3 \\
4 \\
5 \\
6 \\
7 \\
8 \\
9 \\
\text { Geometric mean }\end{array}$ & $\begin{array}{l}20 \\
40 \\
10 \\
20 \\
20 \\
5 \\
20 \\
40 \\
20 \\
18.5\end{array}$ & $\begin{aligned} 20 \\
40 \\
20 \\
20 \\
80 \\
20 \\
10 \\
>80 \\
20 \\
29.4\end{aligned}$ & $\begin{array}{l}40 \\
80 \\
10 \\
20 \\
10 \\
5 \\
20 \\
40 \\
20 \\
20.0\end{array}$ & $\begin{array}{r}40 \\
40 \\
10 \\
>80 \\
20 \\
5 \\
10 \\
40 \\
40 \\
25.2\end{array}$ & $\begin{array}{l}20 \\
80 \\
20 \\
40 \\
10 \\
1.25 \\
20 \\
40 \\
20 \\
18.5\end{array}$ & $\begin{array}{r}80 \\
>80 \\
20 \\
>80 \\
10 \\
10 \\
10 \\
>80 \\
20 \\
43.3^{*}\end{array}$ & $\begin{array}{l}20 \\
40 \\
10 \\
40 \\
20 \\
5 \\
20 \\
40 \\
10 \\
18.5\end{array}$ & $\begin{aligned} 40 \\
>80 \\
40 \\
40 \\
40 \\
5 \\
20 \\
>80 \\
20 \\
37.1^{*}\end{aligned}$ \\
\hline
\end{tabular}

*p $<0.05$, Wilcoxon matched pairs signed rank test.

than the inhaled drug. ${ }^{45}$ Godden et al found that inhaled fenoterol suppressed cough produced by solutions low in chloride ions in smokers and non-smokers, ${ }^{9}$ while Pounsford et al found that inhaled salbutamol suppressed citric acid induced cough in asthmatic but not non-asthmatic subjects. ${ }^{10}$ These differences may be related to the use of different methods of inducing cough.

Most cough suppressants are prescribed in an oral formulation. Our study has confirmed the effectiveness of pholcodine in this form, but failed to show an effect of oral salbutamol alone or as an addition to pholcodine. These findings relate only to acute, artificially induced cough in normal subjects. Active cough suppressants have, however, shown similar effects in such acute studies and in the suppression of spontaneous cough in patients. ${ }^{6}$ Our results suggest that $\beta$ stimulants are unlikely to be helpful in the suppression of cough in the absence of increased bronchial reactivity.

We are grateful to G Pover, C Dash, and Glaxo Pharmaceuticals Limited for their help with this study.

\section{References}

1 Corrao WM, Braman SS, Irwin RS. Chronic cough as the sole presenting manifestation of bronchial asthma. $N$ Engl J Med 1979;300:633-7.

2 Hannaway PJ, Hopper DK. Cough variant asthma in children. JAMA 1982;247:206-8.

3 Ellul-Micaleff R. Effect of terbutaline sulphate in chronic "allergic" cough. Br Med J 1983;287:940-3.

4 Peltola H, Michelsson K. Efficacy of salbutamol in treatment of infant pertussis demonstrated by sound spectrum analysis. Lancet 1982; i:310-2.

5 Pavesio D, Ponzone A. Salbutamol and pertussis. Lancet 1977;i:150-1.

6 Salem H, Aviado D. Preclinical and clinical investigation of drugs. II-Antitussive agents. Drug Information Journal 1974;74:111-43.

7 Rees PJ, Clark TJH. Assessment of antitussive effects by citric acid threshold. Br J Dis Chest 1983;77:94-7.

8 Bickerman HA, Itkin SE. Further studies on the evolution of antitussive agents employing experimentally induced cough in human subjects. Clin Pharmacol Ther 1960;1:180-91.

9 Godden D, Lowry R, Borland C, Higenbottam T. The effects of an inhaled beta-agonist cough chemoreceptor threshold [abstract]. Thorax 1984;39:232.

10 Pounsford JC, Saunders KB, Davidson RN. Effect of bronchodilators on the cough response to citric acid in normal subjects and asthmatics [abstract]. Thorax 1984;39:712. 